\title{
SHEAR STRENGTH OF THE SELECTED TYPES OF PELLETS
}

\author{
Gabriel Czachor*, Jerzy Bohdziewicz, Krzysztof Kawa \\ Institute of Agricultural Engineering, Wrocław University of Environmental and Life Sciences \\ *Corresponding author: gabriel.czachor@up.wroc.pl
}

\begin{tabular}{|c|c|}
\hline ARTICLE INFO & ABSTRACT \\
\hline $\begin{array}{l}\text { Article history: } \\
\text { Received: December } 2015 \\
\text { Received in the revised form: } \\
\text { January } 2016 \\
\text { Accepted: April } 2016 \\
\end{array}$ & \multirow{2}{*}{$\begin{array}{l}\text { The usefulness of raw material obtained from oak leaves, waste from } \\
\text { paper mass and fragments of Miscanthus was verified with regard to } \\
\text { pellet production. A batch of pellets produced therefrom was subjected } \\
\text { to technological shear tests with the use of prototype equipment. Also } \\
\text { pellets produced by well-known Polish producers were tested. The } \\
\text { suggested method of technological shear enables obtaining credible } \\
\text { results through standardization of tests conditions. Statistical processing } \\
\text { of results proved that there are significant differences in the values of } \\
\text { shear strength and unit shear work obtained for both group of pellets. An } \\
\text { experimental batch of pellets has a lower density and thus lower shear } \\
\text { strength which limits the scope of industrial application. The research } \\
\text { which was carried out proved that there is a strong correlation between } \\
\text { mechanical strength and density. }\end{array}$} \\
\hline $\begin{array}{l}\text { Key words: } \\
\text { shear strength, } \\
\text { density, } \\
\text { pellet }\end{array}$ & \\
\hline
\end{tabular}

\section{Introduction}

Dynamic development of solid biofuels market forces out the necessity of obtaining new raw materials (Wu et al., 2011; Frączek et al., 2010). Except for the fundamental group which is based on timber raw material, agricultural waste products are even more used: straw, horticultural waste and mixtures of various raw materials (Carone et al., 2011; Gil et al., 2010; Frączek et al., 2010). The applied raw materials and solid biofuels obtained therefrom are constantly subjected to precise requirements described in the European standards. They were listed in the papers by (Garcia-Maraver et al., 2011; CEN/TS 14588). Standardization of the solid biofuel quality depends on the necessity of automation of combustion processes particularly in small boiler houses and elimination of threat from generated dust loading (Vinterbäck, 2004). In this context quality control of fuel, particularly its geometric and physical properties is important (Temmerman et al., 2006; Carone et al., 2011). Nondimensional pellets make the process of loading and transport difficult, their improper density changes the combustion processes and low mechanical strength generates excessive dust loading. It is assumed that the mechanical strength and density are main parameters which describe a physical quality of compacted solid biofuels, such as pellets (Carone et al., 2011). Pursuant to the standards, mechanical durability (DU - mechanical durability) is the most often determined in the test of dynamic dislocation of the pellet batch in the measurement chamber (PN-EN 15210-1: 2010; ASAE S269.4 Dec 96; ÖNORM M 7135), or abrasion resistance (AR - abrasion resistance) is tested in Lignotester device (Bergström et al., 
2008). The measure of strength is a percentage of waste, the most often fraction below 3.15 $\mathrm{mm}$. In the paper by Temmerman et al., (2006) usefulness of both methods was verified and it was found out that the method described in ASEA S standard 269.4 gives the most unrepeatable results. Moreover, shear strength of the pellet mass is investigated with the use of Janike edometer (ASTM D 6128-0615, 2006) and in the compression test where pellet is fragmented on the disc rotating with the speed of $6.5 \mathrm{~m} \cdot \mathrm{s}^{-1}$ or $24.3 \mathrm{~m} \cdot \mathrm{s}^{-1}$ with partition mounted thereto (Wu et al., 2011). Conditions of hitting pellet granules which are falling down on the sliding belt conveyor are simulated. The amount of waste is measured (crushed fragments) on the $3 \mathrm{~mm}$ sieve.

Precise verification of pellet properties is carried out through measurements of strength of single granules in the test of their axial (Starek et al., 2014) or radial compression (Bergström et al., 2008; Carone et al., 2011). In the first case the strength is expressed with MPa and in the second one with $\mathrm{N} \cdot \mathrm{mm}^{-1}$. The objective of this paper was to develop the method and the device for determination of pellet strength on fragmentation based on the measurement of shear strength. The measurement of strength properties of the experimental batch of pellets for verification of the method was carried out and they were compared to those, which were produced in series.

\section{Methodology}

In the laboratory of the Institute of Agricultural Engineering of the University of Life Sciences in Wrocław pellet batches were produced using the oak leaves, waste from paper mass and fragments of Miscanthus as raw material. Raw material after being fragmented and dried to the relative moisture of $11-13 \%$ was granulated on the biomass granulation line type MGL200 produced by KOVO NOWAK, CZ-67101 CITONICE 1 . The obtained pellet was seasoned and then volumetric density $\rho$ was determined for granules selected from each batch of pellet. Density was measured through the mass measurement and geometric dimensions of granules. The measuring balance type WPE 300 (RADWAG, Radom), a maximum relative error $\pm 0.1 \%$ and a digital calliper with precision of $\pm 0.01 \mathrm{~mm}$ were used. Analogous measurement was carried out for the pellet batches produced by popular Polish producers. In the research pellets obtained from defragmented pieces of deciduous and coniferous timber, their mixtures and wheat straw were used.

For realization of the shear test a prototype of the device submitted for patent, number 222187 (Czachor, 2013) was used. The essence of its structure and manner of use were described in the Patent Office Bulletin of the Republic of Poland on 14th April 2014. The basic advantage of the prepared device is simplicity of the shear test performance with the possibility of simultaneous testing of several pairs of pellet granules with a varied diameter. The structure of the device enables precise adjustment of a granule to a specific opening in the measuring device.

Measurements of shearing strength were carried out on Instron 5566 machine with the use of a measurement head up to $10 \mathrm{kN}$ at the speed of a working beam of $2 \mathrm{~mm} \cdot \mathrm{s}^{-1}$. In each batch of pellet at least 30 granules were tested. By processing of results density $\rho$, shear strength $R_{t}$ and unit shear work $W_{t}$ were calculated. For such values, mean values with confidence limit were determined with the use of a statistic packet of Excel program (at the assumed level of significance $\alpha=0.05$ ). Then, relations between the values of $\rho, R_{t}$, and $W_{t}$ 
Shear strength...

were determined. On this basis, the scope of changes of mechanical properties values, which characterize the batches of the investigated pellets, were determined.

The shear strength was determined with the assumption that the shearing stress has a mean value in the entire sheared section. Then, the shear strength is described with the equation (1):

$$
R_{t}=\frac{4 \cdot T_{\max }}{n \cdot \pi \cdot d_{s r}^{2}}
$$

where:

$T_{\max }$ - maximum value of the registered shearing strength, (N)

$n \quad$ - number of shearing surfaces,

$d_{s r} \quad$ - mean shearing diameter, $(\mathrm{mm})$ as:

Shearing work $W$ was determined from the relation (2), force $T$ - dislocation $\lambda$ (Fig. 2)

$$
W=\frac{1}{n} \int_{0}^{\lambda} T(\lambda) \cdot d \lambda
$$

and unit shearing work from the formula (3):

$$
W_{t}=\frac{4 \cdot W}{\pi \cdot d_{s r}^{2}}
$$

\section{Results and discussion}

For assessment of variability of the values of stereometric elements which form a pellet structure, microscopic analysis of the surface of the selected samples with the use of optical stereoscopic microscope Nikon SMZ 1500 was carried out. Figure 1 presents the image of the longitudinal cross-section of Lava Stelmet pellet. The analysed micro-structure is typical for the pellet. The image presents also the direction of impact of shearing strength on the material.

Figure 1 shows that the pelletization process of fragmented particles of wood causes characteristic direction of structure elements. Despite a stochastic method of their arrangement they form with fragments a pseudo-fibre structure which results from a longitudinal pressing. It is also influenced by the results of stresses, micro-cracks perpendicular to the longitudinal axis of pellet. A complex structure causes that shearing leads to total decohesion of a pellet only to small deformation of a pellet in the shearing surface at the maximum force $T_{\max }$. A typical characteristic of force $T$ - dislocation $\lambda$ was presented in figure 2 .

Characteristic of the shearing force - dislocation presented in figure 2 is a resultant of the resistance of several pellets mounted in a device each time. The measure of the resultant shearing work $W$ is a striped field. In order to determine Rt, $\mathrm{W}, \mathrm{Wt}$ the number of sheared surfaces $n$ must be included according to equations 1 , 2, 3. Relation of $R_{t}=\mathrm{f}(\rho), W_{t}=\mathrm{f}(\rho)$ and $W_{t}=\mathrm{f}\left(R_{t}\right)$ was presented in figure 3,4,5. 


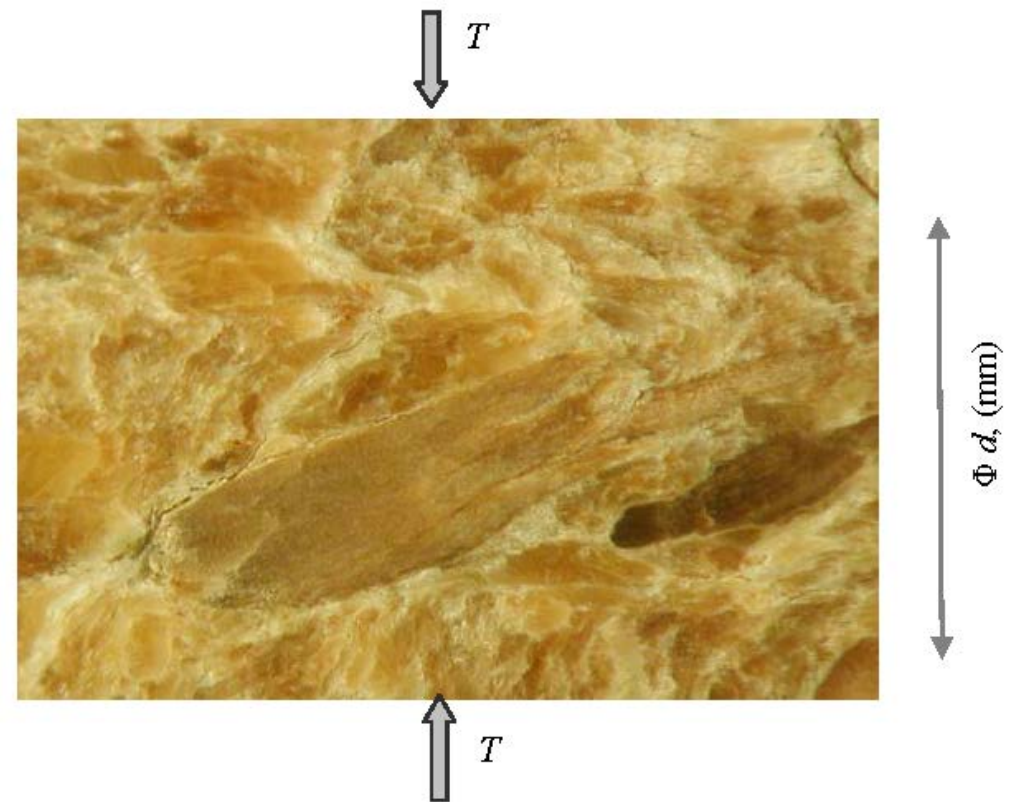

Figure 1. Typical micro-structure of pellet timber

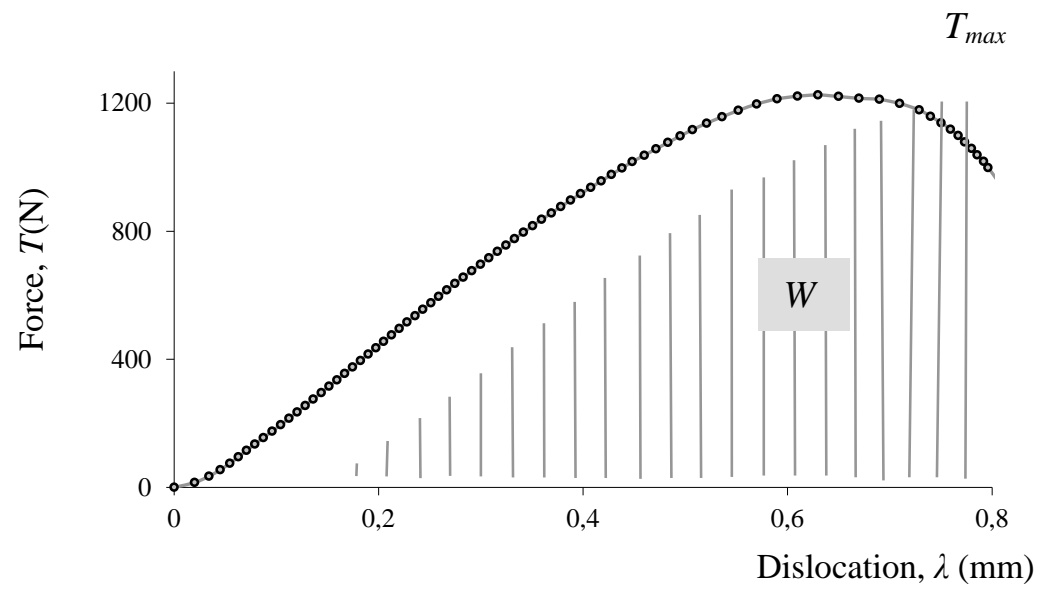

Figure 2. Typical relation shearing force - dislocation, $W$ - shearing work 
The analysed plots (Fig. 3,4,5) of location of points which characterise properties of particular types of pellets were grouped. Mean values with confidence limits were determined. Pellet batches were given the following numbers: 1 - Lava; Stelmet S.A; 2 - strawKOPEX GROUP; 3 - mixture of deciduous and coniferous timber Galaxy; 4 - wheat straw, producer: J W Group sp. z o.o.; 5 - miscanthus; 6 - oak leaves; 7 - paper mass.

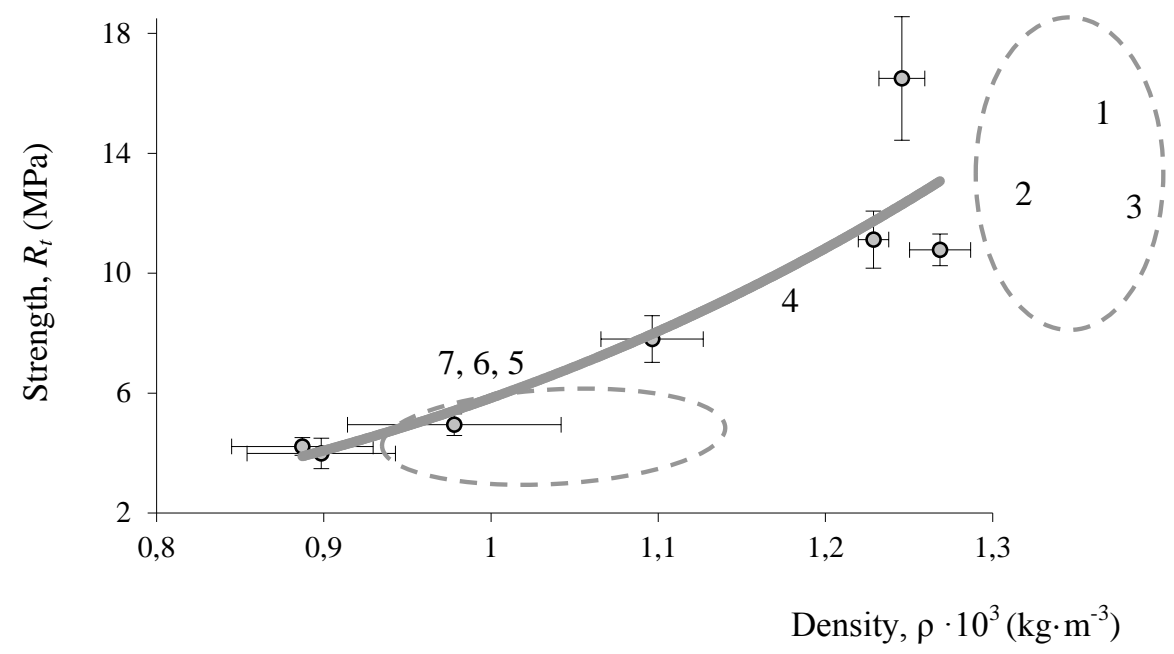

Figure 3. List of values: shearing strength - density of selected pellets

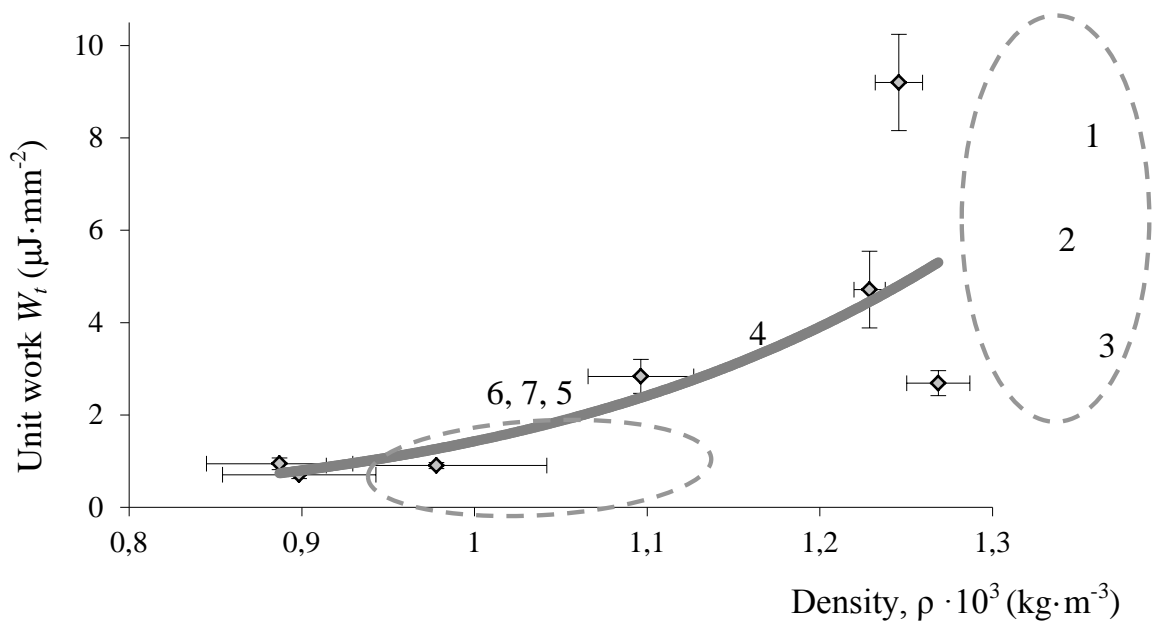

Figure 4. List of values: unit shearing strength - density of selected pellets 


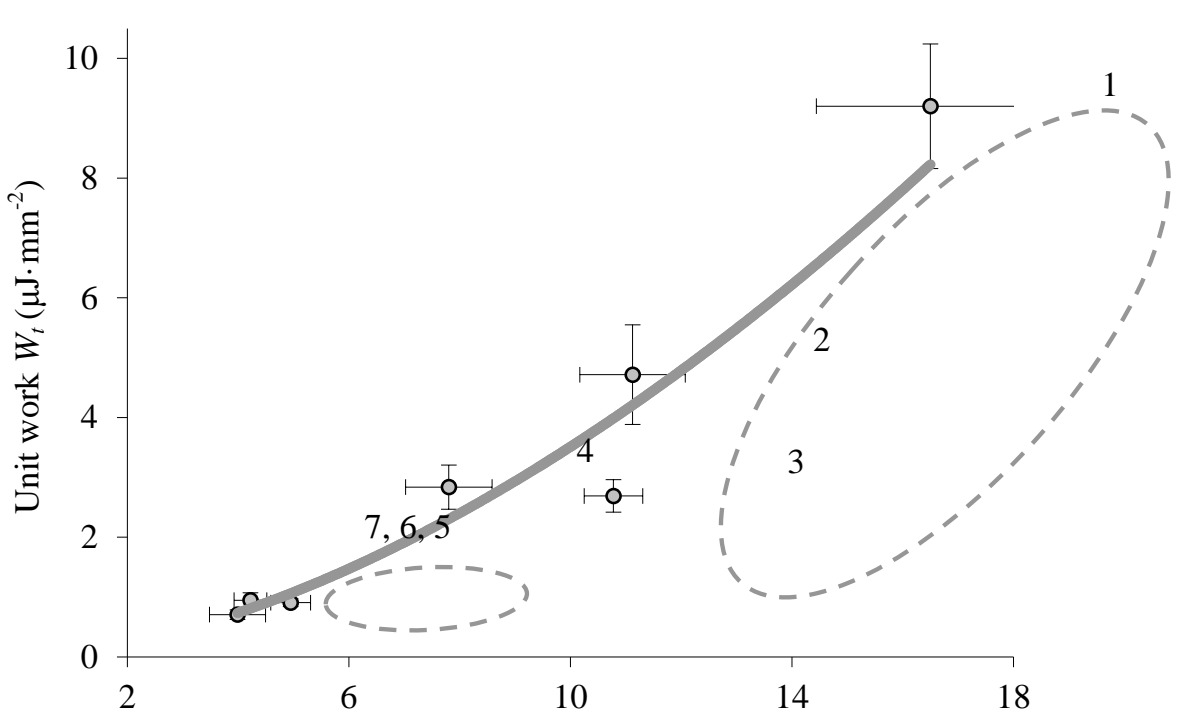

Strength, $R_{t}(\mathrm{MPa})$

Figure 5. List of values; unit shearing stress - shearing strength

The analysis of figures 3, 4, 5 shows that the values of mechanical properties of the experimental batch of pellets in a statistically significant way differ with regard to pellets produced to the industrial scale. Mainly, they have lower density, below the requirements of standards. As a result, particular elements of the experimental structure of pellets batch are weakly related.

Analysis of relations $R_{t}=\mathrm{f}(\rho)$ and $W_{t}=\mathrm{f}(\rho)$ indicates that there is a strong correlation between mechanical properties and density of pellet material. Also the relation $W_{t}=\mathrm{f}\left(R_{t}\right)$ is strongly correlated. The trend to which relations are subject may be described with an equation type $y=\mathrm{a} \cdot x^{\mathrm{b}}$. Values of equation coefficients were presented in table 1

Table 1.

Values of function parameters (trend) $y=a \cdot x^{b}$

\begin{tabular}{lccc}
\hline Function & $\mathrm{a}$ & $\mathrm{b}$ & $\mathrm{r}^{2}$ \\
\hline$R_{t}=\mathrm{f}(\rho)$ & 5.84 & 3.38 & 0.92 \\
$W_{t}=\mathrm{f}(\rho)$ & 1.43 & 5.50 & 0.80 \\
$W_{t}=\mathrm{f}\left(R_{t}\right)$ & 0.07 & 1.70 & 0.95 \\
\hline
\end{tabular}




\section{Conclusions}

1. The suggested method of technological shearing enables simultaneous testing of several pellet granules which makes the obtained results reliable and allows precise determination of the values of mechanical properties. The structure of the measuring device enables precise adjustment of each pellet to the place of its mounting which standardizes the tests conditions. It is particularly significant in the shearing process, which initiates in the tested material a complex condition of stresses.

2. The obtained results show significant differences in the quality of the investigated pellets and confirm a considerable impact of density on the value of shearing strength and unit shearing work of the pellet material. Lower density of the experimental batch of pellets and thus lower mechanical strength limits the scope of their industrial application.

\section{References}

ASAE S269.4 Dec 96. Cubes, pellets and crumbles - definitions and methods for determining density, durability and moisture content.

ASTM D 6128-06. Standard test method for shear testing of bulk solids using the Jenike shear cell.

Bergström, i in. (2008). Effects of raw material particle size distribution on the characteristics of Scots pine sawdust fuel pellets. Fuel Processing Technology, 89, 1324-1329.

Carone, M.T., Pantaleo, A., Pellerano, A. (2011). Influence of process parameters and biomass characteristics on the durability of pellets from the pruning residues of Olea europaea L. Biomass and Bioenergy, 35, 402-410.

Czachor, G. Przyrząd do ścinania technologicznego próbek, zwłaszcza z granulatu opałowego. Uniwersytet Przyrodniczy we Wrocławiu. Polska. Patent nr 222187. WUP 29.07.2016.

Frączek, J. (red.). (2010). Produkcja biomasy na cele energetyczne. PTIR Kraków, ISBN 978-83917053-8-4.

García-Maraver, A., Popov, V., Zamorano. (2011). A review of European standards for pellet quality M. Renewable Energy, 36, 3537-3540.

Gil, M.V., Oulego, P., Casal, M.D., Pevida, C., Pis, J.J. (2010). Ubiera F. Mechanical durability and combustion characteristics of pellets from biomass blends. Bioresource Technology, 101, 8859-8867.

ÖNORM M 7135, Preßlinge aus naturbelassenem Holz und naturbelassender Rinde - Pellets und Briketts -Anforderungen und Prüßbestimmungen.

PN-EN 15210-1: 2010. Biopaliwa state - Oznaczenie wytrzymałości mechanicznej brykietów i peletów-Cz 1: Pelety.

Specyfikacja techniczna. (2004). Published standard. CEN/TS 14588 CEN/TC 335. Solid biofuels. Terminology, definitions and descriptions.

Starek, A., Kośko, M., Zarajczyk, J., Kowalczuk, J., Tatarczak, J., Zawiślak, K., Sobczak, P., Mazur, J., Szmigielski, M. (2014). Wpływ surowca i parametrów roboczych granulatora nowej konstrukcji na odporność peletów na ściskanie. Zeszyty Problemowe Postępów Nauk Rolniczych, 578, 121-129.

Stegelmeier, M., Schmitt, V. EM., Kaltschmitt, M. (2011). Pelletizing of autumn leaves-possibilities and limits. Biomass Conv. Bioref. 1, 173-187.

Temmerman, M., Rabier, F., Jensen, P., Hartmann, H., Böhm, T. (2006). Comparative study of durability test methods for pellets and briquettes. Biomass and Bioenergy, 30, 964-972.

Wu, M.R., Schott, D.L., Lodewijks, G.(2011). Physical properties of solid biomass. Biomass and Bioenergy, 35, 2093-2105.

Vinterbäck, J. (2004). Pellets 2002: the first world conference on pellets. Biomass and Bioenergy, 27, 513-520. 


\section{WYTRZYMALOŚĆ NA ŚCINANIE WYBRANYCH RODZAJÓW PELETÓW}

Streszczenie. Weryfikowano przydatność surowca pozyskanego z liści dębu, odpadów z masy papierowej oraz fragmentów miskantusa do produkcji peletów. Wytworzoną z tych surowców partię peletów poddano testom technologicznego ścinania $\mathrm{z}$ wykorzystaniem prototypowego oprzyrządowania. Testowano również pelety wyprodukowane przez znanych polskich producentów. Proponowana metoda technologicznego ścinania umożliwia uzyskanie wiarygodnych rezultatów poprzez standaryzację warunków testu. Statystyczna obróbka wyników wykazała, że istnieją istotne różnice w wartościach wytrzymałości na ścinanie oraz jednostkowej pracy ścinania uzyskane dla obu grup peletów. Eksperymentalna partia peletów cechuje się mniejszą gęstością a tym samym mniejszą wytrzymałością na ścinanie, co ogranicza zakres jej przemysłowego stosowania. Przeprowadzone badania potwierdziły, że istnieje silna korelacja pomiędzy wytrzymałością mechaniczną a gęstością.

Słowa kluczowe: wytrzymałość na ścinanie, gęstość, pelet 